\title{
PERLINDUNGAN HUKUM BAGI PENGGUNA KARTU BRIZZI SEBAGAI ALAT PEMBAYARAN NON TUNAI
}

\author{
Oleh \\ Bagus Dwi Handoko, Adi Suliantoro
}

\begin{abstract}
ABSTRAKSI
Nasabah adalah konsumen pengguna jasa perbankan yang memiliki hak mendapatkan perlindungan hukum dalam melakukan transaksi. Perkembangan teknologi mendorong nasabah untuk melakukan transaksi secara non tunai (cashless). Produk-produk uang elektronik memberikan solusi kepada konsumen berupa kemudahan bertransaksi. Salah satu produk uang elektronik yang beredar di masyarakat adalah Brizzi yng diterbitkan oleh PT Bank Rakyat Indonesia (Persero) Tbk. Seiring meningkatnya penggunaan Brizzi di masyarakat, permasalahan terkait penggunaannya pun seringkali dialami oleh pemegang kartu. Permasalahan tersebut menjadi salah satu resiko yang dihadapi pemegang kartu. Dalam proses penyelesaian masalah inilah seringkali hak nasabah dalam perlindungan konsumen dikesampingkan.

Dari latar belakang tersebut, maka dalam penelitian ini dirumuskan permasalahan sebagai berikut : (1). Bagaimana perlindungan hukum bagi konsumen pengguna kartu Brizzi menurut Undang-Undang? (2) Apa saja resiko yang ditanggung oleh pengguna kartu Brizzi dalam bertransaksi? (3) Bagaimana penyelesaian masalah apabila terjadi hal yang merugikan konsumen pengguna kartu Brizzi.

Metode pendekatan yang digunakan dalam penelitian ini adalah yuridis normatif. Dalam pendekatan yuridis, hukum dilihat sebagai norma sehingga pendekatan ini mengacu pada peraturan perundang-undangan yang berlaku. Pendekatan normatif digunakan untuk menganalisis hukum sebagai suatu perangkat aturan perundangan yang bersifat normatif.

Berdasarkan penelitian yang dilakukan, resiko yang dihadapi pengguna kartu antara lain gagal top up tapi saldo terdebet, jaringan offline, Brizzi rusak,hilang, pasif, dan permasalahan biaya. Permasalahan tersebut dapat diselesaikan oleh Bank BRI sebagai bank penerbit melalui layanan Call BRI 14017, Customer Service di unit kerja, maupun melalui media sosial BRI. Maksimal penyelesaian adalah 14 (empat belas) hari kerja dihitung dari diterimanya komplain oleh Bank BRI. Perlindungan hukum bagi nasabah terkait transaksi pembayaran non tunai khususnya kartu BRIZZI menurut Peraturan Otoritas Jasa Keuangan No.1/POJK.07/2013 tentang Perlindungan Konsumen Sektor Jasa Keuangan adalah penerapan prinsip transparansi, perlakuan yang adil, keandalan, kerahasiaan dan keamanan informasi konsumen, serta penanganan pengaduan dan penyelesaian sengketa konsumen secara sederhana, cepat dan biaya terjangkau. Bank BRI perlu meningkatkan kualitas layanan dan meningkatkan keamanan bagi nasabah pemegang kartu Brizzi yang berkebutuhan khusus.
\end{abstract}


KATA KUNCI :

Perlindungan Hukum, Brizzi, Nasabah

\section{PENDAHULUAN}

Peranaan teknologi informasi dan komunikasi di era globalisasi telah menempati posisi yang amat strategis karena menghadirkan suatu dunia tanpa batas, jarak, ruang dan waktu yang berdampak pada peningkatan produktivitas dan efisiensi. Salah satu tanda era globalisasi masyarakat dunia, termasuk Indonesia adalah adanya perkembangan alat pembayaran yang semakin pesat dan maju. Awalnya sistem barter antar barang yang diperjualbelikan adalah alat pembayaran yang lazim yang digunakan di era pra-modern. Adanya berbagai kesulitan dengan sistem barter mendorong munculnya satuan tertentu yang memiliki nilai pembayaran, yang dikenal dengan istilah uang. Hingga saat ini uang menjadi salah satu alat pembayaran utama yang berlaku di masyarakat.

Seiring dengan kemajuan teknologi, kehidupan manusia kini berjalan dengan sangat cepat, efektif, dan efisien. Sejarah telah membuktikan bahwa perkembangan alat pembayaran telah berubah-ubah bentuknya mulai dari uang logam, uang kertas konvensional, hingga kini alat pembayaran telah mengalami evolusi berupa data yang ditempatkan pada suatu wadah atau yang disebut dengan alat pembayaran elektronik.

Kartu e-money (electronic money) adalah kartu yang memiliki fungsi sebagai uang digital. Kartu emoney ini termasuk dalam kartu prabayar yang memiliki nilai uang yang tersimpan secara elektronik dalam media server atau chip. Saldo di kartu e-money adalah nilai dari uang anda yang tersimpan, uang di emoney bisa digunakan untuk beragam pembayaran di merchant / toko yang menerima pembayaran dengan e-money. Ternyata, tidak semua e-money dapat digunakan sebagai E-Toll. Sehingga konsumen harus berhati-hati dalam memilih emoney untuk membayar tol dengan metode cashless. Ketersediaan saldo pun menjadi hal yang sangat penting.

Pengguna e-money dapat dikatakan sebagai konsumen, karena menurut Pasal 1 ayat (2) Undang Undang Nomor 8 Tahun 1999 tentang Perlindungan Konsumen, konsumen adalah setiap orang pemakai barang dan/atau jasa yang tersedia dalam masyarakat, baik kepentingan diri sendiri, keluarga, orang lain, maupun mahluk hidup lain dan tidak untuk diperdagangkan. Dan terhadap setiap pengguna e-money dilindungi hak-haknya sebagaimana amanat daripada Pasal 4 Undang Undang Perlindungan Konsumen. Sehingga dapat dikatakan bahwa perlindungan terhadap pengguna emoney mutlak adanya. Bisa dikatakan konsumen sebagai pihak yang lebih lemah, hal ini diakui secara Internasional sebagaimana tercermin dalam Resolusi Majelis Umum Persatuan Bangsa-Bangsa No.A/Res/39/248 Tahun 1985Tentang Guidelines Consumer Protection, yang menghendaki agar konsumen dimanapun mereka berada, dari segala bangsa, mempunyai hak-hak dasar tertentu, terlepas dari status 
sosialnya. Yang dimaksud dengan hak-hak dasar tersebut antara lain adalah hak untuk mendapat informasi yang jelas, benar dan jujur, hak untuk mendapat keamanan dan keselamatan, hak untuk memilih, hak untuk didengar, hak untuk mendapat ganti rugi, hak untuk mendapat kebutuhan dasar manusia.

Terlalu banyak kartu produk perbankan membuat kita bingung akan manfaat dari kartu BRIZZI, karena selama ini kita sudah memiliki kartu debit ATM BritAma maupun Simpedes. Kartu Brizzi adalah uang elektronik dari Bank BRI yang dapat di gunakan sebagai alat pembayaran non tunai. Kartu BRIZZI ini berisi uang elektronik yang sebagian fungsinya sama dengan kartu Debit maupun Kredit yaitu dapat dijadikan sebagai alat belanja non tunai di berbagai tempat atau mercant yang menyediakan mesin EDC. Kartu Brizzi agar dapat di gunakan sebagai alat pembayaran, maka sebelumnya di isi dahulu (Topup) melalui ATM atau bisa juga di merchant yang tersedia di mini market (Alfamart, Indomart) ada juga di sekitar jalan Tol.

Pemerintah menutup layanan transaksi tunai di jalan tol sebagai bagian dari Gerakan Nasional Non Tunai. Artinya, pengendara mobil wajib punya uang elektronik (emoney) yang bisa digunakan buat bayar tol. Resmi sudah, bayar tol mesti pakai e-toll card. Kewajiban ini diterapkan mulai 31 Oktober 2017 di semua gerbang jalan tol. Selama ini gerbang-gerbang tol masih memisahkan antara pintu dengan sistem pembayaran tunai dan nontunai. Kelak, hanya sistem non-tunai alias gerbang tol otomatis (GTO) yang tersedia.

Dalam perkembangannya sampai saat ini, kartu Brizzi belum bisa dikatakan sempurna dengan berbagai masalah yang dialami langsung oleh para nasabah/konsumen pengguna Kartu Brizzi khususnya di Semarang. Hal ini dapat dilihat dari biaya gagalnya Top Up Kartu Brizzi dan berbagai kendala pembayaran melalui gardu Tol yang dirasakan relatif memakan waktu cukup lama serta sangat beresiko dalam hal keamanan.

Berdasarkan latar belakang yang disampaikan diatas, maka penulis sangat tertarik tentang bagaimana perlindungan yang diberikan terhadap pengguna Kartu Brizzi. Apabila pada kondisi tersebut kita sudah berada dekat gardu Tol dan baru mengetahui Top Up gagal, maka akan menimbulkan kerugian bagi konsumen dimana harus mengeluarkan biaya uang tunai sebesar dua kali lipat biaya di gardu Tol tersebut. Terkait permasalahan mengenai Brizzi, ternyata Bank meminimalisir adanya berita yang merugikan nama baik institusi dengan menampung semua pengaduan terkait produk BRI di media sosial Tweeter dan penulis ingin membantu masyarakat untuk memecahkan permasalahan.

\section{METODE PENELITIAN}

\subsection{Tipe Penelitian}

Tipe Penelitian adalah penelitian hukum YuridisNormatif, yaitu tipe penelitian yang difokuskan untuk mengkaji 
penerapan norma-norma hukum positif. ${ }^{1}$ Penelitian ini diawali dengan mengkaji berbagai peraturan dan ketentuan yang mendasari proses pemberian kartu e money bagi nasabah berikut fitur-fitur yang dimilikinya, serta menghubungkan dengan hukum perlindungan konsumen terkait perlindungan hukum bagi nasabah komplain dalam bertransaksi menggunakan kartu Brizzi yang mungkin timbul resiko dalam transaksi tersebut. Dengan metode ini diharapkan ada pijakan yang kuat mengenai perlindungan hukum bagi nasabah komplain dalam bertransaksi menggunakan kartu Brizzi, khususnya pada transaksi pembelian dan pembayaran tol.

\subsection{Spesifikasi Penelitian}

Spesifikasi penelitian ini merupakan penelitian yang bersifat deskriptif, yaitu diberikan gambaran menyeluruh tentang apa dan bagaimana perlindungan hukum bagi nasabah pengguna kartu Brizzi atas resiko yang mungkin terjadi dan bertujuan untuk menemukan pengetahuan yang seluas-luasnya terhadap objek penelitian pada suatu masa tertentu. ${ }^{2}$

\subsection{Sumber Data}

\subsubsection{Data Sekunder}

\footnotetext{
${ }^{1}$ Lili Rasjidi, Menggunakan Teori dalam Analiis di Bidang Ilmu Hukum, Bandung, 2007

${ }^{2}$ Hidayat syah.2010.Pengantar Umum Metodologi Penelitian Pendidikan Pendekatan Verivikatif. Pekanbaru : Suska Pres.
}

Penulisan skripsi ini menggunakan sumber data sekunder, yaitu data yang diperoleh langsung dari buku-buku, laporan, arsip maupun berbentuk dokumen yang diambil dari PT Bank Rakyat Indonesia (Persero) Tbk kantor cabang Semarang Pattimura. Data sekunder berupa berbagai bahan pustaka yang memaparkan segala sesuatu mengenai perlindungan konsumen dan bidang perbankan. Data sekunder tersebeut meliputi :

1) Kitab Undang-Undang Hukum Perdata

2) Undang-Undang No 8 Tahun 1999 tentang Perlindungan

Konsumen

3) Undang-Undang No 10 Tahun 1998 tentang Perubahan atas Undang-Undang No 7 Tahun 1992 tentang Perbankan

4) Undang-Undang No 21 tahun 2011 tentang Otoritas Jasa Keuangan

5) Peraturan Bank Indonesia Nomor 16/8/PBI/2014 Tahun 2014 tentang Perubahan Atas Peraturan Bank Indonesia Nomor 11/12/PBI/2009 tentang Uang Elektronik (Electronic Money)

6) Peraturan Bank Indonesia (PBI) Nomor 7/6/PBI/2005 tentang Transparansi Informasi Produk Bank dan 


\begin{tabular}{|c|c|}
\hline & $\begin{array}{l}\text { Penggunaan } \\
\text { Pribadi Nasabah }\end{array}$ \\
\hline \multirow[t]{5}{*}{ 7) } & Peraturan \\
\hline & Indonesia \\
\hline & 7/7/PBI/2005 \\
\hline & Penyelesaian \\
\hline & Pengaduan Nasabah \\
\hline \multirow[t]{4}{*}{ 8) } & Peraturan Bank \\
\hline & Indonesia No 8/5/2006 \\
\hline & tentang $\quad$ Mediasi \\
\hline & Perbankan \\
\hline \multirow[t]{6}{*}{ 9) } & Peraturan Otoritas Jasa \\
\hline & Keuangan $\quad$ No \\
\hline & 1/POJK.07/2013 \\
\hline & tentang Perlindungan \\
\hline & Konsumen Sektor Jasa \\
\hline & Keuangan \\
\hline \multirow[t]{2}{*}{ 10) } & Service Level \\
\hline & $\begin{array}{l}\text { Agreement Bank BRI } \\
2017\end{array}$ \\
\hline
\end{tabular}

\subsubsection{Data Primer} (Sebagai Tambahan)

Data Primer adalah data yang diperoleh secara langsung dari penelitian di PT Bank Rakyat Indonesia (Persero) Tbk kantor cabang Semarang Pattimura, berupa laporan pengaduan nasabah pengguna kartu Brizzi dalam periode Januari 2017 - Maret 2018.

\subsection{Metode Pengumpulan Data}

Metode Pengumpulan Data merupakan teknik atau cara yang dilakukan untuk mengumpulkan data. Metode menunjuk suatu cara sehingga dapat diperlihatkan penggunaannya melalui angket, wawancara, pengamatan, tes, dkoumentasi dan sebagainya.
Pengumpulan data
dilakukan dengan studi pustaka, yaitu melakukan penelitian bahan hukum sekunder terkait Kitab Undang-Undang Hukum Perdata, Undang-Undang No 8 Tahun 1999 tentang Perlindungan Konsumen, Undang-Undang No

10 Tahun 1998 tentang Perubahan atas UndangUndang No 7 Tahun 1992 tentang Perbankan, UndangUndang No 21 tahun 2011 tentang Otoritas Jasa Keuangan, Peraturan Bank Indonesia Nomor 16/8/PBI/2014 Tahun 2014 tentang Perubahan Atas Peraturan Bank Indonesia Nomor 11/12/PBI/2009 tentang Uang Elektronik (Electronic Money), Peraturan Bank Indonesia (PBI) Nomor 7/6/PBI/2005 tentang Transparansi Informasi Produk Bank dan Penggunaan Data Pribadi Nasabah, Peraturan Bank Indonesia No 7/7/PBI/2005 tentang Penyelesaian Pengaduan Nasabah, Peraturan Bank Indonesia No 8/5/2006 tentang Mediasi Perbankan, Peraturan Otoritas Jasa Keuangan No 1/POJK.07/2013 tentang Perlindungan Konsumen Sektor Jasa Keuanga, Service Level Agreement Bank BRI 2017.

\subsubsection{Studi Kepustakaan}




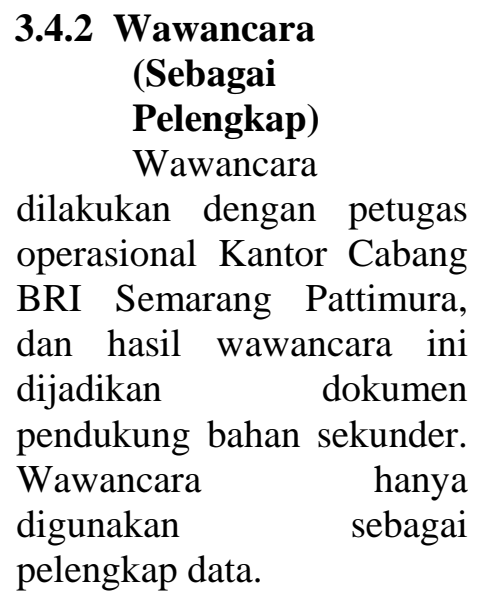

\subsection{Metode Penyajian Data}

Hasil penelitian disajikan dalam bentuk uraian - uraian yang tersusun secara sistematis. Data sekunder yang diperoleh akan dihubungkan dengan data lainnya, kemudian disesuaikan dengan permasalahan yang diteliti.

\subsection{Metode Analisis Data}

Metode yang dilakukan adalah analisa data secara deskriptif kualitatif. Deskriptif kualitatif, yaitu mengambil data-data yang berkaitan dengan permasalahan yang akan diteliti sehingga dapat diuraikan secara deskriptif, kualitatif, dan komprehensif, yaitu menggambarkan kenyataan yang berlaku dan masih ada kaitannya dengan aspek-aspek hukum yang berlaku. Di samping itu, peneliti memperhatikan adanya keterhubungan antara data primer dengan data sekunder dan di antara bahan-bahan hukum yang dikumpulkan. Peneliti melakukan editing, dengan maksud agar kelengkapan dan validitas data dan informasi terjamin. Peneliti mengklasifikasikan data secara sistematis, artinya semua data ditempatkan dalam kategorikategori. ${ }^{3}$

Pada

akhirnya, menginterpretasikan bahan hasil penelitian pada pengertian, nomanorma, teori-teori hukum serta doktrin yang berkaitan dengan pokok permasalahan. Kemudian dikorelasikan dengan fakta-fakta yang relevan, sehingga dapat ditarik menjadi sebuah kesimpulan.

\section{HASIL DAN PEMBAHASAN}

Perbedaan antara registered dan unregistered atau kartu Anjungan Tunai Mandiri (ATM) dengan kartu BRIZZI, akan lebih jelas dan rinci dijelaskan sebagai berikut : ${ }^{4}$

1.

encatatan Identitas Pemegang

Kartu : Data identitas pemegang kartu Anjungan

Tunai Mandiri (ATM) tercatat dan terdaftar pada penerbit sedangkan data identitas pemegang kartu BRIZZI tidak tercatat pada penerbit / tidak harus menjadi nasabah penerbit.

2. Nilai uang elektronik yang tersimpan: Pemegang kartuAnjungan Tunai Mandiri (ATM) memiliki batas nilai uang elektronik yang tersimpan dalam media chip/server paling banyak sebesar Rp. 5.000.000 (lima juta rupiah) sedangkan

\footnotetext{
${ }^{3}$ Salim HS, 2013, Penerapan Teori Hukum pada penelitian Tesis dan desertasi,Jakarta,PT.

Rajagrafindo,hlm 26

${ }^{4}$ Peraturan Bank Indonesia No.

11/12/PBI/2009
} 
pemegang kartu BRIZZI memiliki batas nilai uang elektronik yang tersimpan dalam media chip/server paling banyak sebesar Rp. 1.000.000 (satu juta rupiah).

3. Keamanan : Pada saat pemegang kartu BRIZZI melakukan transaksi berbeda dari segi keamanan dengan transaksi menggunakan Anjungan Tunai Mandiri (ATM) karena proses transaksi dengan menggunakan uang elektronik tidak membutuhkan Personal Identification Number (PIN), dibandingkan dengan Anjungan Tunai Mandiri (ATM) yang membutuhkan Personal Identification Number (PIN) untuk proses transaksi sesuai dengan Surat Edaran Bank Indonesia Nomor 13/22/DASP/2011 tentang Implementasi Teknologi Chip dan Penggunaan Personal Identification Number (PIN) pada Kartu ATM dan/atau Kartu Debit yang Diterbitkan di Indonesia. ${ }^{5}$

4. Informasi Pemegang Kartu : Perbedaan antara informasi pemegang kartu BRIZZI dengan pemegang Anjungan Tunai Mandiri (ATM) adalah informasi pemegang kartu Uang elektronik (e-money) ada yang tercatat maupun tidak tercatat pada penerbit, sesuai dengan bunyi pasal $1 \mathrm{~A}$ ayat (1) Peraturan Bank

${ }^{5}$ Romawi I.B.1-2 Surat Edaran Bank Indonesia Nomor 13/22/DASP/2011
Indonesia Nomor

16/8/PBI/2014 tentang

Perubahan atas Peraturan

Bank Indonesia Nomor

11/12/PBI/2009 tentang Uang

Elektronik berbeda dengan

Anjungan Tunai Mandiri (ATM) dimana semua data tentang informasi disimpan oleh penerbit.

5. Resiko Penyalagunaan : penyalagunaan yang terjadi pada uang elektronik sangat mudah terjadi, karena sistem keamanan yang belum bisa melindungi pemegang kartu uang elektronik, dimana pada saat kartu BRIZZI dicuri atau hilang bisa digunakan oleh orang lain dengan mudah dan gampang, karena tidak terhubungan dengan rekening, sehingga tidak memerlukan Personal Identification Number (PIN) dan/atau Tanda Tangan sebagai otorisasi transaksi/untuk menyetujui transaksi, artinya kerugian/resiko

penyalagunaan ini sepenuhnya ditanggung oleh pemegang kartu uang elektronik (e-money), berbeda dengan Anjungan Tunai Mandiri (ATM) dimana telah dijelaskan dalam berbagai regulasi peraturan salah satunya menurut Suarat Edaran Bank Indonesia Nomor 14/17/DASP/2012 tanggal 7 juni 2012 Perihal Perubahan atas Surat Edaran Bank Indonesia Nomor 11/10/DASP/2009 tanggal 13 April $2009 \quad$ perihal 


\begin{abstract}
Penyelenggaraan Kegiatan Alat Pembayaran dengan Menggunakan Kartu. Maka, terlihat bawa ketika terjadi penyalagunakan terhadap pengguna alat pembayaran menggunakan kartu hakhaknya sebagai konsumen dapat dilindungi sehingga resiko kerugian yang dialaminya tidak ditanggung sendirian, tetapi dapat dibantu oleh bank penerbit.
\end{abstract}

6. Penyimpanan Dana : Penyimpanan dana dari kartu BRIZZI berbeda dengan penyimpanan dana dari Anjungan Tunai Mandiri (ATM), dimana untuk nilai uang kartu BRIZZI telah tercatat dalam instrument $e$ money (Kartu) yang sering dikenal dengan nama stored value, sehingga dana yang tercatat sepenuhnya berada dalam penguasaan konsumen atau pemegang kartu uang elektronik, dibandingkan dengan Anjungan Tunai Mandiri (ATM) dimana tidak ada pencatatan dana yang tersimpan dalam instrument kartu, hal ini mengakibatkan dana sepenuhnya berada dalam pengelolaan bank (Penerbit Kartu) sepanjang belum ada otorisasi dari nasabah untuk melakukan pembayaran.

7. Proses Transaksi : Kartu BRIZZI merupakan kartu prabayar dimana pengelolaan dana sepenuhnya berada dalam pengawasan pemegang kartu, dan semua dana atau simpanan juga berada dalam pengawasan pemegang kartu, dana dalam uang elektronik tersimpan dalam instrument kartu BRIZZI, sehingga pada saat transaksi tidak perlu memerlukan otorisasi berupa Personal Identification Number (PIN) dan/atau Tanda Tangan untuk menyetujui transaksi yang akan dan sedang dilakukan, berbeda dengan Anjungan Tunai Mandiri (ATM) dimana setiap transaksi yang dilakukan tidak bisa secara langsung, melainkan membutuhkan otorisasi berupa Personal Identification Number (PIN) dan/atau Tanda Tangan untuk menyetujui transaksi, hal ini disebabkan karena dananya tidak tersimpan dalam instrument kartu melainkan tersimpan dalam rekening nasabah, dalam hal ini bank penerbit yang memiliki kewenangan untuk mengawasi dan mengelola sebelum adanya otorisasi dari nasabah pada saat melakukan transaksi.

8. Hubungan Hukum antara pemegang kartu dengan Penerbit : Pada penggunaan uang elektronik, karena sifatnya yang prabayar maka hubungan hukum antara penerbit dan pemegang kartu bersifat jual beli, dimana penerbit menjual sebuah alat penyimpan data berupa stored value card (kartu prabayar) berbeda dengan Anjungan Tunai Mandiri (ATM) dimana hubungan 
hukum antara pemegang kartu dengan bank penerbit didasari pada perjanjian simpan menyimpan uang sesuai dengan Pasal 1 angka (5) UU Perbankan salah satu bentuk simpanan adalah tabungan pada bank. Anjungan Tunai Mandiri (ATM) hanya merupakan fasilitas yang diberikan kepada nasabah/pengguna jasa bank untuk memudahkan penggunaan simpanan. ${ }^{6}$

Peraturan Bank Indonesia No. 16/8/PBI/2014 menyatakan bahwa berdasarkan pencatatannya uang elektronik memiliki 2 jenis yaitu registered dan unregistered. Uang Elektronik (electronic money) registered adalah uang elektronik yang data identitas pemegangnya terdaftar dan tercatat pada penerbit. Uang elektronik (electronic money) unregistered adalah uang elektronik yang data identitas pemegangnya tidak terdaftar dan tidak tercatat pada penerbit.

Kedua jenis pencatatannya uang elektronik tersebut, terdapat resiko yang diketahui dan/atau tidak diketahui oleh nasabah / konsumen pengguna uang elektronik. Salah satu resikonya adalah ada sebagian resiko dari jenis pencatatan registered dan unregistered, bahwa pengguna uang elektronik jenis pencatatan (registered) tidak harus menanggung semua resiko yang akan timbul karena mendapat perlindungan dari Bank. Sebaliknya, pengguna uang

\footnotetext{
${ }^{6}$ Undang -Undang Nomor 10 Tahun 1998 tentang Perubahan Atas Undang-Undang Nomor 7 Tahun 1992 tentang Perbankan
}

elektronik jenis pencatatan (unregistered) harus menanggung semua resiko yang akan timbul tanpa mendapat perlindungan dari Bank.

Berdasarkan resiko jenis pencatatan (unregistered) tersebut, maka resiko kehilangan kartu BRIZZI (merupakan jenis pencatatan unregistered) yang mungkin dialami oleh nasabah berakibat tidak mendapatkan penggantian nilai uang / saldo pada kartu tersebut oleh Bank BRI. Artinya, pelaku usaha (Bank) tidak memenuhi kewajibannya sesuai dengan Pasal 7 pada UndangUndang No. 8 Tahun 1999 mengenai Perlindungan Konsumen dimana dijelaskan bahwa pelaku usaha wajib memberi kompensasi, ganti rugi dan/atau penggantian atas kerugian akibat penggunaan, pemakaian dan pemanfaatan barang dan/atau jasa yang diperdagangkan.

Resiko lainnya adalah disaat membeli kartu BRIZZI di merchant yang sudah bekerja sama dengan Bank BRI, masyarakat mendapatkan kartu BRIZZI (merupakan jenis pencatatan unregistered) tetapi tidak dilengkapi brosur penggunaan serta sering tidak ada penjelasan informasi mengenai aturan yang terdapat pada kartu BRIZZI oleh penjual. Artinya, pelaku usaha (Bank) juga tidak memenuhi kewajibannya sesuai dengan Pasal 8 pada UndangUndang No. 8 Tahun 1999 mengenai Perlindungan Konsumen dimana dijelaskan bahwa pelaku usaha dilarang memproduksi dan/atau memperdagangkan barang dan/atau jasa yang tidak memenuhi atau tidak sesuai dengan standar yang dipersyaratkan dan ketentuan peraturan perundang-undangan. 
Sedangkan, menurut Pasal 4 Undang- Undang No. 8 Tahun 1999 mengenai Perlindungan Konsumen dimana dijelaskan bahwa seharusnya nasabah berhak atas informasi yang benar, jelas, dan jujur mengenai kondisi dan jaminan barang dan/atau jasa. Tetapi faktanya, dikarenakan keterbatasan pengetahuan produk dan kurang baiknya pelayanan oleh petugas di merchant yang menjual kartu BRIZZI tanpa dilengkapi brosur penggunaan tersebut, maka konsumen tidak mengetahui akibat hukum atas segala resiko yang timbul setelah melakukan transaksi jual beli kartu BRIZZI.

Berdasarkan beberapa resiko diatas, seharusnya nasabah mengetahui bahwa uang elektronik unregistered digunakan sebagai alat pembayaran kepada pedagang yang bukan merupakan penerbit uang elektronik tersebut. Nilai uang ini bukan merupakan simpanan sebagaimana dimaksud dalam undang-undang yang mengatur mengenai perbankan, sehingga tidak diberikan bunga dan tidak dijamin oleh Lembaga Penjamin Simpanan (LPS). Uang elektronik lebih merupakan pengalihan bentuk dari uang tunai.

Kedua jenis pencatatan diatas memiliki kelebihan dan risikonya masing-masing. Meski fungsinya sama, e-moneyregistered memiliki keamanan lebih dari yang unregistered. Untuk hal itulah, Bank Indonesia menyarankan masyarakat memilih e-money registered. Artinya, e-money registered itu memiiliki identitas pemegang dan tercatat resmi pada penerbit uang elektronik. Sebaliknya, e-money unregistered bisa diperlakukan layaknya uang biasa. Maka, jika hilang pemilik tidak akan rugi besar. Dalam hal nominal, nilai e-money registered yang bisa disimpan paling banyak sebesar Rp. 5.000.000 (lima juta rupiah), sedangkan nilai e-money unregistered bisa disimpan paling banyak sebesar Rp. 1.000.000 (satu juta rupiah). $^{7}$

\section{KESIMPULAN DAN SARAN}

\subsection{Kesimpulan}

\subsubsection{Perlindungan Hukum Terhadap Pengguna Kartu BRIZZI}

a. Menurut UndangUndang No 8 Tahun 1999 tentang Perlindungan Konsumen, perlindungan konsumen adalah segala upaya yang menjamin adanya kepastian hukum untuk memberi perlindungan kepada konsumen.

b. Menurut Kitab UndangUndang Hukum Perdata pasal 1365 KUHPer, perlindungan konsumen adalah terpenuhinya hakhak konsumen termasuk pemberian ganti rugi yang wajar apabila terjadi hal-hal yang merugikan konsumen.

c. Menurut Ketentuan Bank Indonesia No

\footnotetext{
${ }^{7}$ Surat Edaran Bank Indonesia No. 11/11/DASP tahun 2009
} 


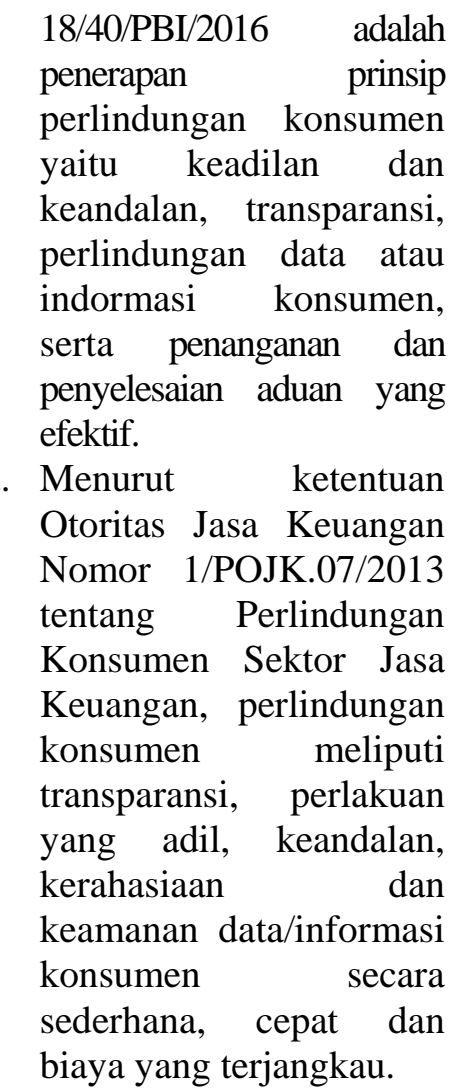

\subsubsection{Resiko Penggunaan Kartu Brizzi Dalam Bertransaksi}

Resiko yang timbul atas transaksi menggunakan kartu BRIZI antara lain : kegagalan isi ulang saldo karena offline atau timeout, kemungkinan gagalnya transaksi dengan faktor fisik kartu rusak atau kartu pasif, belum semua transaksi bisa memakai kartu BRIZZI karena belum semua merchant bekerja sama dengan penerbit khususnya Bank BRI, risiko seluruh uang hilang ketika pengguna

\author{
kehilangan kartu \\ BRIZZI.
}

\subsubsection{Penyelesaian Masalah Resiko Pengguna Kartu BRIZZI}

Penyelesaian

pengaduan nasabah yang bertransaksi

menggunakan kartu BRIZI dapat diselesaikan dengan pelaporan ke Customer Service, Call BRI 14017, dan bagian terkait masalah tersebut. Apabila pengaduan nasabah tidak terselesaikan, maka Bank BRI Semarang Pattimura akan memberikan sarana mediasi dengan pimpinan / level jabatan dari management yang lebih tinggi. Untuk komplain yang tidak terselesaikan melebihi batas waktu yang disepakati, maka akan dilakukan mediasi sesuai ketentuan Peraturan Otoritas Jasa Keuangan Nomor 1/POJK.07/2013 tentang Perlindungan Konsumen Sektor Jasa Keuangan. Tetapi, Bank BRI Semarang Pattimura selalu memutus alur mediasi agar tidak diserahkan ke tingkat lembaga yang berkompeten atau pengadilan sekaligus dengan cara melakukan pendekatan-pendekatan ke nasabah. 


\subsection{Saran}

\subsubsection{Saran Bagi Pihak Bank BRI}

a. Bank BRI perlu membuat ketentuan terkait nasabah yang berkebutuhan khusus, seperti tuna netra, dengan menyediakan tulisan timbul atau huruf braille pada kartu BRIZZI dan mesin Top Up, sehingga dapat memenuhi kebutuhan nasabah namun tetap mengacu pada aspek keamanan serta memperhatikan perlindungan nasabah yang memiliki kebutuhan khusus.

b. Maraknya penawaran fasilitas produk perbankan terutama alat pembayaran non tunai, maka akan dapat mengalihkan perhatian nasabah sehingga dimungkinkan nasabah akan beralih ke produk selain BRIZZI. Bank BRI Semarang Pattimura seharusnya

meningkatkan suatu pelayanan dan startegi yang baik serta melakukan rutinitas aktivitas Corporate Social Responsibility untuk menjaga loyalitas nasabah BRI Semarang Pattimura sehingga nasabah tidak beralih pada produk lain dan senantiasa mendorong orang lain untuk menggunakan produk BRIZZI.

c. Bagi Bank BRI Semarang Pattimura, penelitian ini diharapkan dapat memberikan banyak masukan, ide dan sumber informasi bagi pihak Bank BRI Semarang Pattimura khususnya dalam meningkatkan Mutu Layanan Jasa dan Produk agar dapat memberikan kepuasan bagi nasabahnya serta untuk mempertahankan layanan yang menguntungkan dimasa yang akan datang. Beberapa saran mengenai peningkatan Mutu Layanan Jasa dan Produk tersebut adalah sebagai berikut :

a) Mutu Jasa Layanan denganmenambah alternatif Hotline BRI melalui jejaring sosial resmi sesuai perkembangan zaman, yaitu jejaring sosial Instagram, Path, Flickr, My Space, Pinterest, XING, Google+, dan masih banyak lagi. Berdasarkan alternatif jejaring sosial tersebut, maka nasabah / konsumen dapat dengan mudah menyampaikan keluhannya. Selain itu, diharapkan waktu 
pelayanan nasabah oleh Frontliner dapat dipercepat dengan menambah meja dan petugas Quick Service di kantor Cabang / Unit / Teras BRI atau dapat menambah armada Mobil Pelayanan Keliling di setiap kecamatan kabupaten.

b) Mutu ProdukKartu BRIZZI dimasa yang akan datang diharapkan terdapat keterangan di sisi belakang berupa tulisan timbul mengenai peraturan tertulis tentang segala resiko kerugian atas penggunaan kartu tersebut dari segi financial. Maka, dapat menjadi sebuah ilmu pengetahuan, wawasan, dan referensi bagi pengguna kartu BRIZZI.

Berdasarkan beberapa manfaat tersebut, diharapkan hasil penelitian diatas bermanfaat sebagai sumbangan pemikirandalam menyebarluaskan ilmu pengetahuan kepada masyarakat umum.

\subsubsection{Saran Bagi Pihak Nasabah}

a. Nasabah perlu meningatkan wawasan dan pengetahuan terkait perlindungan konsumen sehingga mengetahui secara detail apabila mengalami transaksi yang merugikan, terutama terkait kartu BRIZZI.

b. Nasabah harus lebih aktif menanyakan karakteristik produk dan jasa bank sebelum akhirnya memutuskan untuk memilih produk yang dikehendaki.

\section{DAFTAR PUSTAKA}

\section{Buku :}

Andrian Sutedi, 2014, Hukum Otoritas Jasa Keuangan, Raih Asa sukses, Jakarta.hal.91

Az. Nasution, Aspek Hukum Perlindungan Konsumen : Tinjauan Singkat Undang

Bank Indonesia, 2001, Paper Kajian EMoney, Bank Indonesia, Jakarta, Hal 12-13.

Booklet Perbankan Indonesia, Maret 2014, hlm.4

Djoni S. Ghazali dan Rachmadi Usman, Hukum Perbankan, Sinar Grafika, Jakarta, 2010, hlm. 1.

Fuadi R. Serfianto DP, dkk, 2012, Untung dengan Kartu Kredit, Kartu ATM-Debit, \& Uang Elektronik, Visi Media, Jakarta, Hal. 98.

Gatot Supramono, Hukum Uang di Indonesia, (Bekasi: Gramata Publishing, 2014), hlm. 52. 
Heri Sucheri, Total Consumer : Percepatan Laba Sepanjang Masa (Solo : Metamograf. 2012 hlm.67

Hidayat syah.2010.Pengantar Umum Metodologi Penelitian Pendidikan Pendekatan Verivikatif. Pekanbaru : Suska Pres.

Lili Rasjidi, Menggunakan Teori dalam Analiis di Bidang Ilmu Hukum, Bandung, 2007

Melakukan Transaksi E-Money, (Denpasar: Universitas Udayana,2013) Hlm 23

Miru, Ahmadi. Prinsip-Prinsip Perlindungan Hukum Bagi Konsumen di Indonesia. Jakarta.Raja Grafindo, 2011

N.H.T. Siahaan, 2005, Hukum Konsumen : Perlindungan Konsumen dan Tanggungjawab Produk, Panta Rei, Jakarta,

Ni Nyoman Anita, Perlindungan Hukum Bagi Pemegang Uang Elektronik Dalam

Pusat Bahasa Departemen Pendiidkan Nasional , 722

Rajagrafindo,hlm 26

Saleskit Produk BRI april 2018

Salim HS, 2013, Penerapan Teori Hukum pada penelitian Tesis dan desertasi,Jakarta,PT.

Service Level Agreement Bank BRI 207

Sentot Imam Wahjono, Managemen Pemasaran Bank . Yogyakarta : Graha Ilmu, 2010 hlm.84

Tri Hendro, Bank \& Institusi Keuangan Non Bank di Indonesia, (Yogyakarta: UPP STIM YKPN, 2014), hlm. 9.

Undang No.8 Tahun 1999-LN.1999 No.42, (Jakarta : Media Hukum dan Keadilan,2003) Hlm.48
Wawancara dengan Ika Trisnawati Lia, tanggal 21 Juni 2018 di Bank BRI Kantor Cabang Semarang Pattimura.

Wawancara dengan Sdr.Tri Kartika Yuliana, Supervisor Layanan Operasional BRI Semarang Pattimura, tanggal 2 Februari 2018

Yopi Gunawan dan Kristian, Perkembangan Konsep Negara Hukum dan Pancasila, Refika Aditama, Bandung, 2015 hlm.1

\section{Peraturan Perundangan :}

Kitab Undang-Undang Hukum Perdata

UU No. 8 Tahun 1999 tentang Perlindungan Konsumen

UU No. 21 Tahun 2011 tentang Otoritas Jasa Keuangan

Peraturan Bank Indonesia (PBI) Nomor 16/8/PBI/2014 tentang Uang Elektronik

Peraturan Bank Indonesia Nomor 20/6/PBI/2018 tentang Uang Elektronik

Peraturan Otoritas Jasa Keuangan Nomor 1/POJK.07/2013

Peraturan Presiden RI No 82 tahun 2016 tentang Strategi Nasional Keuangan Inklusif.

\section{Jurnal Online :}

Arshinta Sekar Bidari. 2013. "Politik Hukum Otoritas Jasa Keuangan sebagai Lembaga Pengawas Sektor Perbankan di Indonesia”, Universitas Sebelas Maret.Tesis www.ojk.go.id/ 